\title{
METODYKA ZARZAZDZANIA RYZYKIEM W BUDOWNICTWIE PODZIEMNYM INFRASTRUKTURY MIAST
}

DOI: 10.33141/po.2020.04.04

\author{
Maria Krechowicz
}

Przegląd Organizacji, Nr 4(963), 2020, s. 28-37

www.przegladorganizacji.pl ๑) Towarzystwo Naukowe Organizacji i Kierownictwa (TNOiK)

\section{Wprowadzenie}

W dzisiejszych czasach na całym świecie można zaobserwować intensywną rozbudowę infrastruktury podziemnej miast. Wynika to z rozrastania się miast, konieczności zaopatrzenia nowych osiedli w media, potrzeby budowy nowych rurociągów w miejsce uszkodzonych w wyniku wieloletniej eksploatacji. Niektóre przedsiębiorstwa zajmujące się budową infrastruktury miast zdecydowały się na wdrożenie innowacyjnych technologii bezwykopowych, takich jak mikrotunelowanie, horyzontalny przewiert sterowany (ang. Horizontal Directional Drilling - HDD) oraz przecisk hydrauliczny. Te nowoczesne technologie umożliwiają wbudowywanie rurociągów pod przeszkodami (np. autostradami, torami kolejowymi, rzekami, jeziorami itp.), w terenie silnie zurbanizowanym oraz w obszarach o szczególnych walorach środowiskowych. Często są one bardziej atrakcyjne niż tradycyjna budowa rurociągu w wykopie pod względem ekonomicznym, technicznym, formalnoprawnym i ekologicznym.

Wiele projektów w nowoczesnym budownictwie podziemnym należy traktować jako przedsięwzięcia o charakterze innowacyjnym, którym towarzyszy wysokie ryzyko. Aby uchronić się przed podejmowaniem błędnych decyzji przed przystąpieniem do bezwykopowej budowy rurociągu, należy wziąć pod uwagę możliwości wystąpienia różnorodnych trudności mogących zaistnieć $\mathrm{w}$ trakcie realizacji inwestycji. Wnikliwa identyfikacja, analiza i wyznaczenie ryzyka, połączone $\mathrm{z}$ doborem odpowiednich reakcji mających na celu jego zmniejszenie, pozwalają na uniknięcie dodatkowych kosztów i chroni przed niepożądanymi konsekwencjami prawnymi (Gierczak, 2014a, s. 71). Niezwykle istotne jest zatem zapewnienie spójności i skuteczności przeprowadzania procesu zarządzania ryzykiem w przedsiębiorstwach zajmujących się bezwykopową budową sieci podziemnych. Brak rozpoznania w tej kwestii często stawia pod znakiem zapytania ukończenie inwestycji z pozytywnym wynikiem.

Celem pracy jest zaprezentowanie kompleksowej metodyki zarządzania ryzykiem w nowoczesnym budownictwie podziemnym infrastruktury miast. W niniejszej pracy omówiono istotę zarządzania ryzykiem w budownictwie podziemnym rurociągów. Przeanalizowano również 3 wybrane, reprezentatywne przypadki zastosowania różnych strategii zarządzania ryzykiem w budownictwie podziemnym rurociągów. Zaprezentowano autorską metodykę zarządzania ryzykiem dla inwestycji bezwykopowej budowy rurociągów. Podjęta tematyka stanowi 


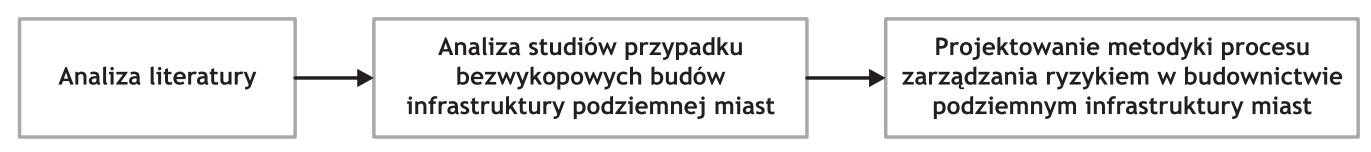

Rys. 1. Model badawczy

Źródto: opracowanie własne

uzupełnienie i kontynuację prac badawczych realizowanych przez autorkę (Gierczak, 2014, s. 148-156; Gierczak, 2014b, s. 67-77), w których zaprezentowano własną metodykę ilościową i jakościową oceny ryzyka (dotyczącą etapu 1 procesu zarządzania ryzykiem). Wartością dodaną niniejszej pracy będzie przedstawienie kompleksowej metodyki procesu zarządzania ryzykiem, obejmującej wszystkie 5 etapów procesu. Na rysunku 1 pokazano model badawczy.

\section{Idea zarządzania ryzykiem}

K lasyczna definicja ryzyka podaje, że jest to prawdopodobieństwo zaistnienia zdarzenia ocenianego negatywnie (Pszczołowski, 1978, s. 215). Konieczne jest rozważenie szerszych definicji ryzyka, uwzględniających pozytywne i negatywne wyniki. Ten dualizm ryzyka jest bardzo dobrze odzwierciedlony w chińskim symbolu ryzyka, stanowiącym połączenie niebezpieczeństwa i szansy. Obrazuje on pozytywną i negatywną stronę ryzyka. Należy zauważyć, że ryzyko nie powinno być utożsamiane jedynie z zagrożeniami, a zatem nie należy skupiać się jedynie na minimalizowaniu ryzyka i zabezpieczeniu przed nim, gdyż takie podejście zmniejsza również potencjał szans (Damodaran, 2009, s. 31).

Często pojęcie ryzyka jest mylone $\mathrm{z}$ pojęciem niepewności. Należy pamiętać o konieczności odróżnienia tych pojęć. Niepewność jest związana z brakiem dostępnych informacji o rozpatrywanym zdarzeniu. Występuje ona nawet, gdy uzyskane informacje uważane są za kompletne. Wyróżnia się trzy rodzaje niepewności: przypadkowość (bak określonego wzorca), rozmytość (nieprecyzyjność definicji, wieloznaczność pojęć) i niekompletność (niepełne informacje lub ich brak) (Van Staveren, 2007, s. 27). Niepewność jest pojęciem szerszym niż ryzyko. Ryzyko jest uznawane za pochodną niepewności o charakterze wymiernym. Uważa się również, że niepewność staje się ryzykiem, kiedy przypisze się jej prawdopodobieństwo (Ostrowska, 2002, s. 28).

W literaturze przedmiotu wyróżnia się trzy główne typy ryzyka: ryzyko czyste i spekulacyjne (pure and speculative risk), ryzyko przewidziane i nieprzewidziane (foreseen and unforeseen risk), ryzyko związane $\mathrm{z}$ dostarczanymi informacjami i ich interpretacją (information an interpretation risk) (Van Staveren, 2007, s. 34-38). Ryzyko czyste dotyczy zdarzeń niepożądanych, które zawsze skutkują niekorzystnym wynikiem. Ryzyko spekulacyjne (oparte na domysłach) może natomiast nieść za sobą zarówno pozytywne, jak i negatywne skutki.

Bezwykopowej budowie rurociągu, tak jak realizacji każdego przedsięwzięcia inwestycyjnego, towarzyszy ryzyko (r), które można zdefiniować jako czteroelementowy zbiór (Rak i in., 2013, s. 65-66):

$$
\mathbf{r}=\left(\mathrm{S}_{\mathrm{i}}, \mathrm{P}_{\mathrm{Si}}, \mathrm{C}_{\mathrm{Si}}, \mathrm{O}_{\mathrm{Si}}\right)
$$

gdzie:

$S_{i}$ - i-ty scenariusz zdarzenia,

$\mathrm{P}_{\mathrm{Si}}$ - prawdopodobieństwo zaistnienia i-tego scenariusza zdarzenia,

$\mathrm{C}_{\mathrm{Si}}$ - wielkość strat spowodowanych zaistnieniem i-tego scenariusza zdarzenia,

$\mathrm{O}_{\mathrm{Si}}$ - stopień ochrony przed i-tym scenariuszem zdarzenia. Można wyróżnić 4 warunki podejmowania decyzji podczas planowania i realizacji projektu: pewność, ryzyko, niepewność i nieokreśloność (Marciniak, Głodziński, 2005, s. 149).

Istnieją różne metody analizy i oceny ryzyka, które mogą być wykorzystane $\mathrm{w}$ budownictwie podziemnym, takie jak np. technika delficka, metoda Crawforda (Pritchard, 2002, s. 109-115, 125-131), metody matrycowe oceny ryzyka, metoda grafów ryzyka, metoda drzew logicznych, metoda FMEA (ang. Failure Mode and Effects Analysis) (Rak, Tchórzewska-Cieślak, 2005, s. 113-116), metoda listy kontrolnej (ang. Check List) (Głodziński, 2015, s. 69-80), metoda „Co-Gdy” (ang. „What-If”), metoda analizy odchyleń, HAZOP (ang. Hazard and Operability Studies), statystyczna metoda analizy ryzyka (Rak, 2006, s. 54-56). Do najbardziej znanych unormowań z zakresu zarządzania ryzykiem należą FERMA, PMBOK, CoSO II, COBIT, PRINCE 2 (Rak, 2013, s. 51-53) oraz ISO 31000:2018.

Zarządzanie ryzykiem jest elementem zarządzania niepewnością, obejmującym zarządzanie ryzykami i szansami (Głodziński, 2014, s. 36). Istotą zarządzania ryzykiem jest zatem dążenie do zwiększenia prawdopodobieństwa i skutków wystąpienia ryzyk korzystnych oraz zmniejszenie prawdopodobieństwa i skutków wystąpienia ryzyk niekorzystnych (A Guide to ..., 2017, s. 287). Jest to proces, który umożliwia przewidywanie i rozwijanie umiejętności przewidywania z pewnym prawdopodobieństwem wystąpienia oczekiwanych i nieoczekiwanych zdarzeń. Można stwierdzić, że skupienie się na niepewnych elementach przyszłości, czyli tzw. identyfikacja czynników ryzyka, ich ocena i odpowiedni dobór strategii eliminowania lub przeciwdziałania niekorzystnym zdarzeniom, jest sprawą kluczową w zarządzaniu ryzykiem (Skorupka, 2005, s. 14).

Można zaobserwować ewolucję dotychczasowych praktyk zarządzania ryzykiem, które okazały się niewystarczające, aby stawić czoło występującym w dzisiejszych czasach zagrożeniom. Efektem tej ewolucji było powstanie nowego standardu ISO 31000:2018 oraz publikacja nowego wydania PMBOK Guide (A Guide to ..., 2017, s. 316-372). 
Nowy standard ISO 31000:2018 kładzie większy nacisk na czerpanie wiedzy z nowych doświadczeń na każdym etapie procesu zarządzania ryzykiem i ciągłe monitorowanie wpływu nowych danych na poziom ryzyka. W standardzie tym zaleca się również tworzenie otwartych modeli systemu, które są dopasowane do potrzeb danej organizacji i regularnie wymieniają informacje zwrotne $\mathrm{z}$ otoczeniem zewnętrznym. Standard zarządzania ryzykiem PMI zakłada planowanie zarządzania ryzykiem, rozpoznawanie ryzyka, jakościową analizę ryzyka, ilościową analizę ryzyka, planowanie reakcji na ryzyko, wprowadzenie reakcji na ryzyko i monitorowanie ryzyka (A Guide to ..., 2017, s. 316). Zaprezentowano tam też szereg narzędzi, które można wykorzystać w zarządzaniu ryzykiem projektu. W standardzie tym nie ma wyraźnie nakreślonych pętli sprzężenia zwrotnego, które są istotną częścią procesu zarządzania ryzykiem. Brak jest pętli sprzężenia zwrotnego umożliwiającej określenie skuteczności różnych rozpatrywanych alternatywnie strategii zarządzania ryzykiem. Brak jest również pętli umożliwiającej wprowadzenie poprawek i dokonanie aktualizacji modelu zarządzania ryzykiem, uwzględniając wymianę informacji z otoczeniem, postęp technologiczny, nowo zdobyte doświadczenia czy nowo zidentyfikowane czynniki ryzyka. Standardy PMI:2017 i ISO 31000:2018 nie precyzują również, $\mathrm{w}$ jaki sposób rozwiązać problemy związane z niepewnością i brakiem precyzji w ocenie ekspertów dokonujących ilościowej analizy ryzyka, które wzrastają wraz z brakiem dostępnych danych i niekompletną wiedzą dotyczącą rozpatrywanego zagadnienia. Doświadczonym specjalistom w praktyce jest bardzo trudno podać konkretne wartości liczbowe dla prawdopodobieństwa zaistnienia poszczególnych ryzyk, a jeśli już takie wartości uda się uzyskać, to specjaliści nie ukrywają, że uzyskane informacje są obarczone dużym błędem i niedokładnością.

\section{Istota zarządzania ryzykiem w nowoczesnym budownictwie podziemnym rurociągów}

$\mathbf{Z}$ arządzanie ryzykiem $\mathrm{w}$ nowoczesnym budownictwie podziemnym to zdefiniowany proces identyfikacji, analizy i reagowania na ryzyko w całym okresie realizacji projektu ukierunkowany $\mathrm{w}$ celu osiągnięcia akceptowalnego poziomu ryzyka, często dzięki zastosowaniu odpowiednio dobranych reakcji na ryzyko. W przypadku budownictwa podziemnego zarządzania ryzykiem nie należy traktować jedynie jako narzędzia stosowanego w celu uniknięcia poważnych katastrof budowlanych, ale także $\mathrm{w}$ celu minimalizacji kosztów i czasu realizacji inwestycji. Wprowadzenie spójnej metodyki zarządzania ryzykiem w złożonych i innowacyjnych projektach budowlanych wspomaga efektywną realizację projektu zgodnie z planowanym harmonogramem i budżetem określonym w umowie (Krechowicz, 2017a, s. 1-10, Krechowicz 2017b, s. 1-10).

Proces zarządzania ryzykiem powinien być dobrze dopasowany do specyfiki danej organizacji, a zatem do wewnętrznego i zewnętrznego kontekstu organizacji i jej profilu ryzyka. Przedsiębiorstwa zajmujące sie bezwykopową budową rurociągów mają specyficzną naturę, która jest wynikiem konieczności szybkiego reagowania na zmienne warunki otoczenia (napotkanie na inne warunki gruntowo-wodne niż spodziewane, napotkanie na niespodziewane przeszkody pochodzenia antropogenicznego, zmienne warunki pogodowe itp.). Proces zarządzania ryzykiem $\mathrm{w}$ budownictwie podziemnym jest procesem dynamicznym, iteracyjnym i wymagającym bardzo szybkiej reakcji na zmiany warunków otoczenia (Van Staveren, 2007 , s. 12). Ryzyko w budownictwie podziemnym jest zatem zależne od czasu, zmiennych warunków otoczenia (czynnik związany z obiektywną oceną rzeczywistych warunków) oraz od zmienności postrzegania rzeczywistości przez człowieka (czynnik związany z interpretacją i subiektywną oceną).

J. Bizon-Górecka i J. Górecki (2013, s. 36) zwrócili uwagę na wysokie ryzyko kosztowe i złożoność zagrożeń $\mathrm{w}$ budowlanych przedsięwzięciach inwestycyjnych. Należy również podkreślić, że wraz z postępem technicznym wzrasta skala, poziom złożoności, unikatowość, ryzyko i niepewność w przedsięwzięciach inwestycyjnych (Głodziński, 2013, s. 18). Aspekty te wymuszają konieczność starannego zarządzania ryzykiem $\mathrm{w}$ nowoczesnym budownictwie podziemnym infrastruktury miast.

W swoich pracach P. Tworek (2012, s. 131; 2013, s. 183-185) zaproponował modyfikację tradycyjnego podejścia do zarządzania ryzykiem $\mathrm{w}$ działalności przedsiębiorstw budowlano-montażowych, wprowadzając koncepcję zintegrowanego zarządzania ryzykiem, według której należy zarządzać ryzykiem w obszarze produkcji budowlano-montażowej, działalności finansowej i inwestycyjnej przedsiębiorstwa. Najistotniejszą grupę metod zarządzania ryzykiem stanowią metody związane z działalnością operacyjną.

Literatura przedmiotu skupia się głównie na opisie pierwszego etapu zarządzania ryzykiem - oceny ryzyka. D. Salem i inni (2017, s. 1014-1021) w swojej pracy zaproponowali metodę oceny ryzyka dla technologii mikrotunelowania $\mathrm{z}$ wykorzystaniem metody AHP (ang. Analytical Hierarchy Process). M. Cheng (2015, s. 48-59) przedstawił metodę oceny ryzyka dla technologii przecisków hydraulicznych, w której wykorzystano analizę rodzajów i skutków możliwych błędów FMEA oraz teorię zbiorów rozmytych. B. Ma i inni (2010, s. 91-97) zaproponowali metodę oceny ryzyka dla technologii HDD. $\mathrm{W}$ modelu tym poszczególne czynniki ryzyka nie zostały rozwinięte do dostatecznego poziomu szczegółowości, zatem przy ocenie ryzyka związanego $z$ danym elementem mogą nie zostać wzięte pod uwagę wszystkie elementy składowe mające istotny wpływ na ostateczny poziom ryzyka. Pozostałe, istotne zdaniem autorki, etapy zaradzania ryzykiem (reagowanie na ryzyko, administrowanie, monitorowanie i finansowanie ryzyka $\mathrm{w}$ bezwykopowych budowach infrastruktury podziemnej miast) nie zostały ujęte w literaturze w sposób modelowy, pozwalający na powstanie kompleksowej metodyki zarządzania ryzkiem dla całego procesu. W literaturze nie znaleziono kompleksowego modelu uwzględniającego strategie zarządzania ryzykiem. W niniejszej pracy autorka podjęła próbę opracowania metodyki kompleksowego zarządzania ryzykiem w nowoczesnym budownictwie podziemnym rurociągów. 
Analiza przypadków zastosowania różnych strategii zarządzania ryzykiem w budownictwie podziemnym rurociągów

W celu zdobycia informacji do ostatecznego zaprojektowania metodyki zarządzania ryzykiem w budownictwie podziemnym dokonano obserwacji przebiegu inwestycji i przeanalizowano przebieg realizacji 3 bezwykopowych budów rurociągów. Zostały one opisane w kolejnych podrozdziałach. Przy zarządzaniu ryzykiem w pierwszej inwestycji przedsiębiorstwo wykorzystało wszystkie propozycje działań zasugerowane przez autorkę oraz opracowany przez nią model oceny ryzyka. W przypadku drugiej inwestycji zastosowano strategie ignorowania ryzyka. Podczas realizacji trzeciej inwestycji nie zastosowano spójnej i skutecznej metodyki zarządzania ryzykiem, ograniczając się do udokumentowania niektórych ryzyk związanych z budową i wybiórczego stosowania reakcji na ryzyko.

\section{Holistyczne i proaktywne zarządzanie ryzykiem w bezwykopowej budowie linii energetycznej w Zastaniu - studium przypadku 1}

Celem inwestycji była bezwykopowa budowa linii energetycznej $15 \mathrm{kV}$ w stalowej rurze osłonowej w miejscowości Zastań pod rzeką Dziwna. Proces zarządzania ryzykiem dla tej inwestycji został przeprowadzony w oparciu o projekt metodyki zaproponowanej przez autorkę niniejszej pracy, którego ostateczna wersja zostanie szczegółowo omówiona w kolejnym rozdziale. Dokonano identyfikacji, analizy i oceny ryzyka, przeprowadzono analizę wrażliwości, zidentyfikowano zdarzenia krytyczne, dla których redukcja ryzyka jest szczególnie istotna. Bez uwzględnienia stosowania strategii reakcji na ryzyko prawdopodobieństwo wystąpienia nieudanej inwestycji wynosiło 80,76\%. Spośród opracowanych przez autorkę 147 strategii reakcji na ryzyko dobrano 56. Następnie, uwzględniając współczynniki redukcji ryzyka dla każdej wybranej reakcji na ryzyko, ponownie obliczono prawdopodobieństwo wystąpienia nieudanej inwestycji, które wyniosło 58,14\%. Maksymalna reduk- cja ryzyka dla pojedynczego zdarzenia niepożądanego była równa 67\%. Na rysunku 2 przedstawiono rozkład rozmytego ryzyka wystąpienia zdarzenia szczytowego (wystąpienia nieudanej inwestycji HDD w Zastaniu) dla przypadku, w którym zastosowano sugerowane reakcje na ryzyko oraz dla przypadku, w którym nie zostały one uwzględnione. Przeprowadzono również staranny proces administrowania, monitorowania i finansowania ryzyka zgodnie $\mathrm{z}$ zaleceniami zawartymi w metodyce zarządzania ryzykiem autorki.

\section{Ignorowanie ryzyka przy bezwykopowej budowie przewodu kanalizacji tłocznej w Katowickiej Strefie Ekonomicznej - studium przypadku 2}

Inwestycja dotyczyła wbudowania przewodu kanalizacji tłocznej wykonanego z rurociągu polietylenowego w Katowickiej Strefie Ekonomicznej na terenie zalewowym. Trasa rurociągu przebiegała wzdłuż osi jezdni. Przed przystąpieniem do realizacji inwestycji nie przeprowadzono analizy ryzyka. W żaden sposób nie udokumentowano istnienia ryzyka. Nie przygotowano również żadnych planów awaryjnych na okoliczność wystąpienia niepożądanych zdarzeń. Przedsiębiorstwo wykonujące przewiert zastosowało zatem typową, świadomą fatalistyczną strategię ignorowania ryzyka.

Wiercenie pilotowe oraz poszerzanie otworu do średnicy przebiegały bez żadnych komplikacji, a problemy pojawiły się dopiero przy wciąganiu rurociągu. Zaobserwowano podniesienie się jezdni na odcinku kilkunastu metrów (od krawężnika do krawężnika). Przyczyną zaistniałej sytuacji było gromadzenie się płuczki wiertniczej pod niweletą jezdni, co z kolei wynikało $\mathrm{z}$ natrafienia podczas wciągania rurociągu na iły, które pęcznieją przy kontakcie $\mathrm{z}$ wodą. $\mathrm{W}$ rezultacie poniesiono dodatkowe koszty związane z naprawą uszkodzonej jezdni oraz wyciąganiem zakleszczonego rurociągu i kosztownych narzędzi wiertniczych. $Z$ uwagi na fakt, że plany awaryjne nie były wcześniej przygotowane, proces likwidacji szkód i odzyskiwania kosztownych narzędzi wiertniczych był długi, a straty z tym związane większe.

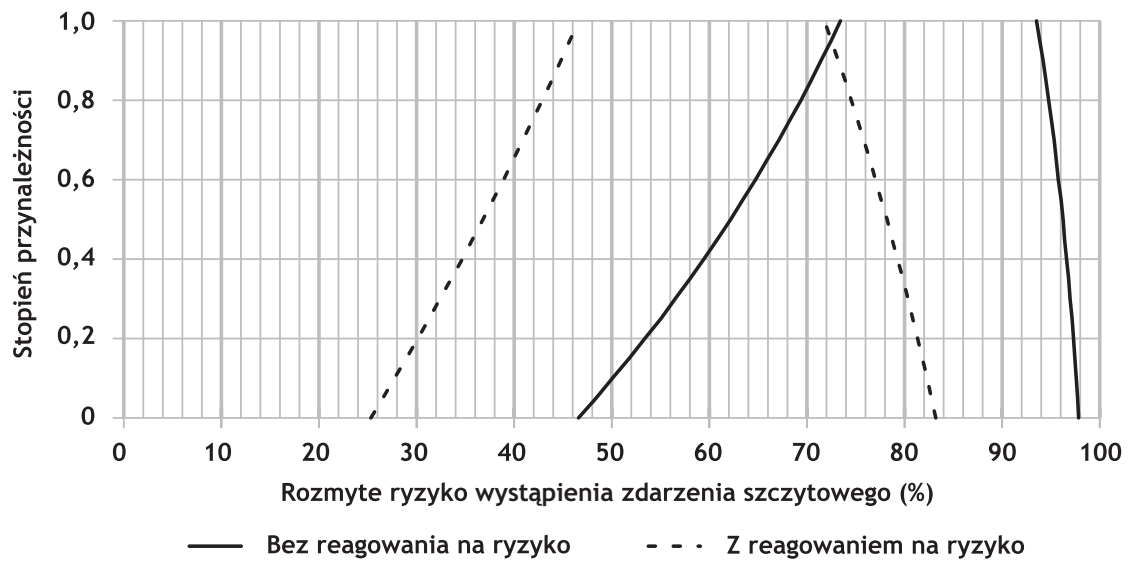

Rys. 2. Rozkład rozmytego ryzyka wystapienia zdarzenia szczytowego Źródto: opracowanie wtasne 
Sytuacji takiej można byłoby uniknąć, gdyby w przedsiębiorstwie wykonującym przewiert wdrożono zaprezentowaną $\mathrm{w}$ niniejszej pracy metodykę zarządzania ryzykiem. Pozwoliłoby to na uniknięcie dodatkowych kosztów związanych z zaistniałą awarią i wywiązanie się z terminu realizacji inwestycji. Taka analiza ryzyka wykazałaby poziom ryzyka wyższy od dopuszczalnego i wtedy należałoby przejść do poszukiwania efektywnych metod zmniejszenia ryzyka, np. poprzez:

- eliminację ryzyka - dokonanie pewnych zmian w założeniach projektowych, np. zmiany trasy przewiertu na taką, gdzie nie występują grunty pęczniejące lub

- redukcję przyczyny ryzyka - wykonanie badań geotechnicznych, zastosowanie domieszek do płynu wiertniczego redukujących pęcznienie gruntu (inhibitorów iłów),

- redukcję efektu ryzyka - pomiar ciśnień płynu wiertniczego w otworze,

- aktywne tolerowanie ryzyka - przygotowanie planów awaryjnych.

\section{Aktywne tolerowanie ryzyka i redukcja przyczyny ryzyka podczas bezwykopowej budowy rurociągu w Rudzie Śląskiej - studium przypadku 3}

Inwestycja dotyczyła wbudowania kabla energetycznego niskiego napięcia w polietylenowej rurze ochronnej w Rudzie Śląskiej. Przed przystąpieniem do realizacji inwestycji nie przeprowadzono kompleksowej analizy ryzyka. Nie zastosowano pełnego omówionego w niniejszej pracy modelu zarządzania ryzykiem. Ograniczono się do udokumentowania istnienia ryzyka poprzez wypisanie krytycznych zdarzeń, mogących wystąpić, zdaniem wykonawcy, podczas bezwykopowej budowy rurociągu. Opisano również procedurę postępowania przy redukcji przyczyny ryzyka natrafienia na niezidentyfikowane przeszkody będące pozostałością po działalności człowieka. Przygotowano plany awaryjne na okoliczność wystąpienia niepożądanych zdarzeń krytycznych. Przedsiębiorstwo wykonujące przewiert zastosowało zatem strategię aktywnego tolerowania ryzyka i redukcji przyczyny ryzyka.

Największym ryzykiem zidentyfikowanym przez wykonawcę był fakt, że nie dysponował on poprawnymi planami z inwentaryzacją sieci podziemnych, a na posiadanych planach znajdowała się jedynie linia pokazująca trasę przebiegu gazociągu bez podania głębokości jego położenia. Podczas realizacji inwestycji zastosowano strategię redukcji przyczyny ryzyka i odkopano istniejący gazociąg. Zmierzono jego głębokość i dobrano bezpieczną głębokość wiercenia. Podczas wiercenia pilotowego nastąpiło jednak uszkodzenie gazociągu. Okazało się, że istniejący gazociąg z głębokości $0,8 \mathrm{~m}$ był prowadzony łukiem na głębokość 1,5 m. Główną przyczyną zaistniałej awarii był brak wprowadzenia kompleksowej strategii zarządzania ryzykiem. Ponadto nieprzeprowadzenie przez wykonawcę kompleksowej analizy ryzyka skutkował pominięciem $\mathrm{w}$ analizie istotnych niepożądanych zdarzeń, które mogłyby wystąpić podczas realizacji inwestycji. Tak więc przygotowana przez wykonawcę lista krytycznych jego zdaniem zdarzeń awaryjnych nie była pełna. Nie zawierała ona prawdopodobieństw i ryzyk dla poszczególnych zdarzeń ocenionych przez grupę ekspertów bazujących na liście czynników koniecznych do uwzględnienia dla każdego zdarzenia niepożądanego. Przy realizacji inwestycji wykonawca nie dysponował przygotowanymi reakcjami na ryzyko dla wszystkich zdarzeń niepożądanych. Dla analizowanej technologii autorka niniejszej pracy opracowała tabelę z proponowanymi 147 strategiami reakcji na ryzyko. Wykonawca pominął następujące strategie zarządzania ryzykiem, które w istotny sposób redukowały procentową wartość ryzyka dla zdarzenia krytycznego „natrafienie na niezidentyfikowane przeszkody będące pozostałością po działalności człowieka":

- redukcję przyczyny ryzyka - wybór sprawdzonej, certyfikowanej firmy prowadzącej badania geotechniczne, zastosowanie kilku metod lokalizacji infrastruktury podziemnej miast, odpowiednią interpretację wyników badań geotechnicznych przez doświadczonego geotechnika lub

- eliminację ryzyka - zmianę trajektorii przewiertu na taką, która nie przebiega w sąsiedztwie istniejącej infrastruktury podziemnej miast.

\section{Analiza porównawcza studiów przypadków}

W celu potwierdzenia zasadności wprowadzenia poszczególnych elementów składowych metodyki zarządzania ryzykiem przeprowadzono analizę porównawczą 3 różnych studiów przypadków (SP) bezwykopowych budów infrastruktury miast pod kątem zastosowanych w praktyce działań (tab. 1). Znak + oznacza, że dane działanie zostało wprowadzone, a - , że nie zostało wykorzystane. Znak + / - oznacza, że dane działanie nie zostało w pełni wprowadzone (np. dla 3 studium przypadku - identyfikacja jedynie najistotniejszych czynników ryzyka, wprowadzenie działań mających na celu redukcję przyczyny lub/i konsekwencji ryzyka, ale tylko dla wybranych czynników ryzyka, opracowanie planów awaryjnych tylko dla wybranych zdarzeń).

Stopień osiągnięcia celów inwestycji (ostatni wiersz tabeli 1) potwierdza zasadność wprowadzenia poszczególnych elementów składowych metodyki zarządzania ryzykiem projektowanej przez autorkę, która zostanie szczegółowo omówiona w kolejnym rozdziale niniejszej pracy.

\section{Proponowana metodyka zarządzania ryzykiem w budownictwie podziemnym infrastruktury miast}

D rzy projektowaniu metodyki procesu zarządzania ryzykiem w budownictwie podziemnym infrastruktury miast przyjęto następujące założenia:

- bazowanie na najnowszych, uznanych metodykach procesu zarządzania ryzykiem (ISO 31000:2018, PMI:2017), 
Tabela 1. Analiza porównawcza 3 różnych studiów przypadków bezwykopowych budów infrastruktury miast pod kątem zastosowanych w praktyce dziatań

\begin{tabular}{|c|c|c|c|}
\hline Opis podjętych działań & SP 1 & SP 2 & SP 3 \\
\hline \multicolumn{4}{|l|}{ Ocena ryzyka i szans } \\
\hline $\begin{array}{l}\text { - identyfikacja czynników ryzyka (ankiety eksperckie, dane literaturowe, } \\
\text { sesje burzy mózgów, analiza scenariuszy awarii) }\end{array}$ & + & - & $+1-$ \\
\hline - identyfikacja potencjalnych możliwości zmiany statusu ryzyko/szansa & + & - & - \\
\hline $\begin{array}{l}\text { - jakościowa analiza ryzyka z zastosowaniem analizy drzewa } \\
\text { niezdatności }\end{array}$ & + & - & - \\
\hline $\begin{array}{l}\text { - ocena prawdopodobieństwa zaistnienia zidentyfikowanych czynników } \\
\text { ryzyka przez grupę ekspertów z wykorzystaniem zmiennych } \\
\text { lingwistycznych }\end{array}$ & + & - & - \\
\hline $\begin{array}{l}\text { - ilościowa analiza ryzyka projektu z zastosowaniem analizy drzewa } \\
\text { niezdatności i teorii zbiorów rozmytych }\end{array}$ & + & - & - \\
\hline $\begin{array}{l}\text { - analiza wrażliwości z zastosowaniem rozmytego wskaźnika ważonego, } \\
\text { kreślenie zdarzeń krytycznych }\end{array}$ & + & - & - \\
\hline - ocena poziomu ryzyka wystąpienia nieudanej inwestycji & + & - & - \\
\hline \multicolumn{4}{|l|}{ Reagowanie na ryzyko } \\
\hline $\begin{array}{l}\text { - dysponowanie katalogiem możliwych do wprowadzenia reakcji na } \\
\text { ryzyko dla wszystkich zidentyfikowanych czynników ryzyka }\end{array}$ & + & - & - \\
\hline $\begin{array}{l}\text { - podejście holistyczne - wprowadzenie działań mających na celu } \\
\text { eliminację ryzyka }\end{array}$ & + & - & - \\
\hline $\begin{array}{l}\text { - podejście holistyczne - wprowadzenie działań mających na celu } \\
\text { redukcję przyczyny lub/i konsekwencji ryzyka }\end{array}$ & + & - & $+/-$ \\
\hline $\begin{array}{l}\text { - podejście fatalistyczne - wprowadzenie działań mających na celu } \\
\text { pasywne tolerowanie ryzyka }\end{array}$ & + & - & - \\
\hline $\begin{array}{l}\text { - podejście fatalistyczne - wprowadzenie działań mających na celu } \\
\text { aktywne tolerowanie ryzyka (plany awaryjne) }\end{array}$ & + & - & $+/-$ \\
\hline $\begin{array}{l}\text { podejście fatalistyczne - wprowadzenie działań mających na celu } \\
\text { transfer ryzyka }\end{array}$ & + & - & - \\
\hline - podejście fatalistyczne - ignorowanie ryzyka & - & + & - \\
\hline $\begin{array}{l}\text { - ponowna ocena ryzyka z uwzględnieniem redukcji ryzyka wynikającej } \\
\text { z planowanych do wprowadzenia reakcji na ryzyko }\end{array}$ & + & - & - \\
\hline $\begin{array}{l}\text { - analiza redukcji ryzyka wynikająca } \mathrm{z} \text { wprowadzenia alternatywnych } \\
\text { reakcji na ryzyko w kilku wariantach }\end{array}$ & + & - & - \\
\hline $\begin{array}{l}\text { Administrowanie ryzykiem (dokumentacja zdarzeń, które wystąpiły } \\
\text { podczas budowy, opracowanie planów awaryjnych na przyszłość na } \\
\text { podstawie zdobytych doświadczeń, opracowanie konserwacji maszyn } \\
\text { i narzędzi) }\end{array}$ & + & - & $+/-$ \\
\hline $\begin{array}{l}\text { Monitorowanie ryzyka (wprowadzenie poprawek i aktualizacja stosowanej } \\
\text { metody analizy ryzyka, uwzględnienie postępu technologicznego w danej } \\
\text { technologii bezwykopowej budowy oraz wprowadzonych nowych urządzeń, } \\
\text { uwzględnienie dodatkowych, nowo odkrytych czynników ryzyka) }\end{array}$ & + & - & - \\
\hline Finansowanie ryzyka (zdefiniowanie źródeł finansowania ryzyka) & + & - & - \\
\hline $\begin{array}{l}\text { Wymiana informacji na dwóch płaszczyznach (wewnątrz organizacji, } \\
\text { między poszczególnymi etapami procesu oraz z otoczeniem na każdym } \\
\text { etapie procesu) }\end{array}$ & + & - & - \\
\hline Osiągnięcie celów inwestycji & Sukces & Porażka & Porażka \\
\hline
\end{tabular}

Źródło: opracowanie własne 
- zapewnienie wymiany informacji na dwóch płaszczyznach: (wewnątrz organizacji, między poszczególnymi etapami procesu oraz z otoczeniem na każdym etapie procesu),

- dopasowanie metodyki do potrzeb i specyfiki organizacji zajmujących się bezwykopową budową infrastruktury podziemnej miast (katalog reakcji na ryzyko możliwych do szybkiego wprowadzenia),

- zapewnienie uniwersalnego charakteru metodyki, tj. możliwości jej zastosowania w projektach budów o różnych wielkościach, $\mathrm{z}$ wykorzystaniem różnych technologii bezwykopowej budowy,

- zapewnienie holistycznego charakteru metodyki, tj. nieograniczanie się do fatalistycznego (ukierunkowanego na wiarę w nieuchronność zdarzeń) podejścia do zarządzania ryzykiem, ale rozważenie ryzyka w bardziej proaktywny (ukierunkowany na skuteczne działanie) sposób, poprzez analizę potencjalnego ryzyka i podjęcie środków w celu zredukowania jego przyczyn lub konsekwencji,

- uwzględnienie pętli sprzężenia zwrotnego umożliwiającej określenie skuteczności różnych rozpatrywanych alternatywnie strategii zarządzania ryzykiem oraz wprowadzenie poprawek i dokonanie aktualizacji modelu zarządzania ryzykiem, uwzględniając postęp technologiczny, nowo zdobyte doświadczenia czy nowo zidentyfikowane czynniki ryzyka.
Proponowana metodyka zarządzania ryzykiem wpisuje się $\mathrm{w}$ trend nakreślony $\mathrm{w}$ standardzie ISO 31000:2018. Podczas opracowywania metodyki zwrócono szczególną uwagę na jej dostosowanie do wymagań nowego standardu i zapewnienie interesariuszom HDD kompleksowej metodyki zarządzania ryzykiem uwzględniającej specyfikę organizacji zajmujących się bezwykopową budową. Uwzględniono również potrzebę czerpania wiedzy z nowych doświadczeń na każdym etapie procesu zarządzania ryzykiem i konieczność ciągłego monitorowania wpływu nowych danych na poziom ryzyka. Proponowana metodyka bazuje również na strukturze zarządzania ryzykiem nakreślonej w metodyce PMI:2017.

$\mathrm{Na}$ rysunku 3 przedstawiono proponowaną metodykę procesu zarządzania ryzykiem w budownictwie podziemnym infrastruktury miast.

Podczas etapu oceny ryzyka należy dokonać identyfikacji czynników ryzyka, obliczyć prawdopodobieństwa wystąpienia poszczególnych zdarzeń niepożądanych, określić ich konsekwencje, określić jednoznacznie poziom ryzyka dla każdego zdarzenia oraz dla całego projektu. Należy również przeprowadzić analizę wrażliwości w celu wyznaczenia krytycznych zdarzeń niepożądanych dla analizowanej bezwykopowej budowy, dla których w szczególności należy zarządzać ryzykiem. Powinno się również dokonać identyfikacji

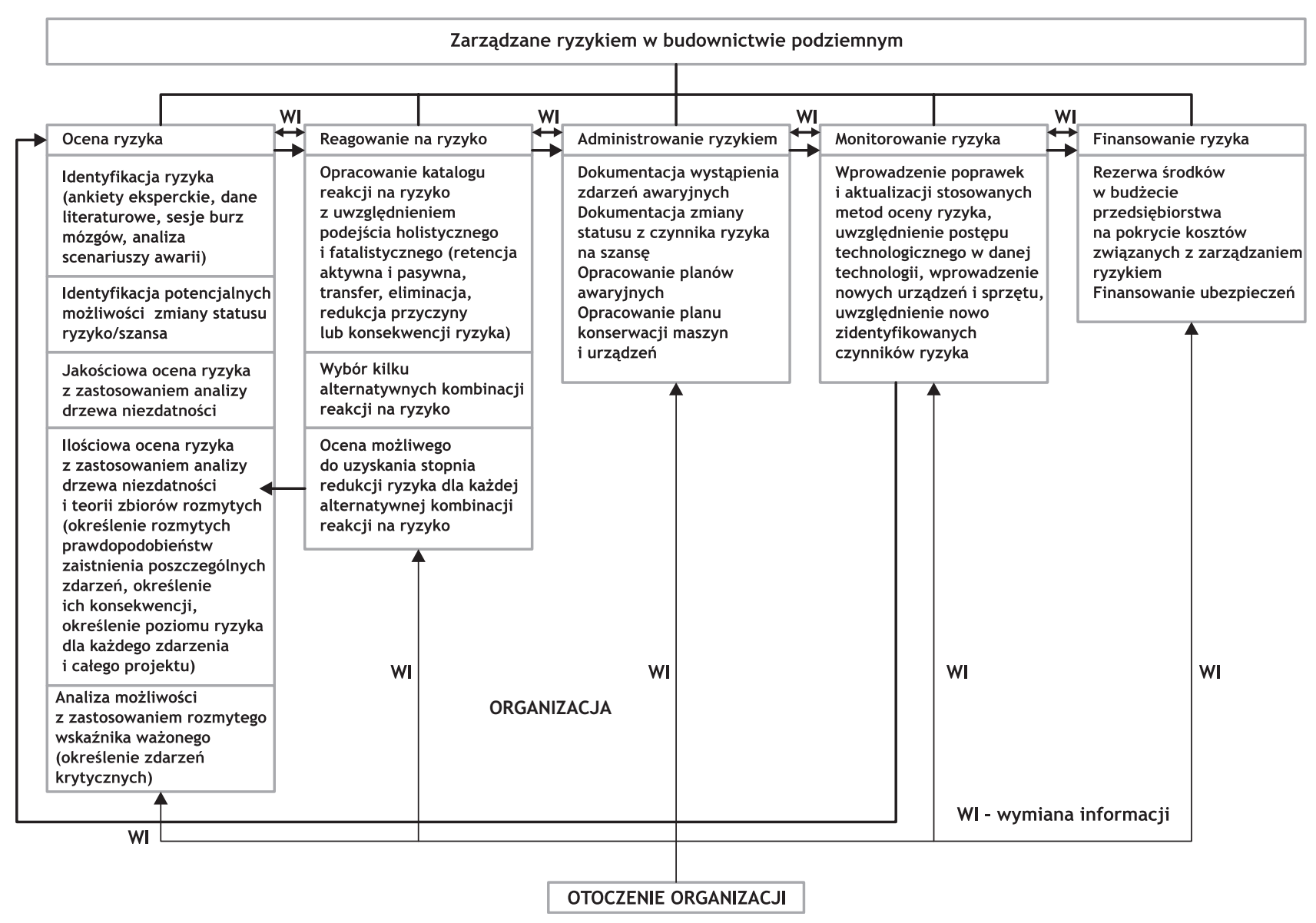

Rys. 3. Proponowana metodyka procesu zarządzania ryzykiem $w$ budownictwie podziemnym infrastruktury miast Źródto: opracowanie wtasne na podstawie: ISO 31000:2018, PMI:2017 
potencjalnych możliwości zmiany statusu czynnika ryzyka na szansę. Autorka do jakościowej analizy ryzyka $\mathrm{w}$ nowoczesnym budownictwie podziemnym zaleca wykorzystać następujące narzędzia: analizę literatury krajowej i zagranicznej opisującej różne bezwykopowe budowy, analizę scenariuszy awarii, ankietyzację przedsiębiorstw krajowych i zagranicznych zajmujących się bezwykopową budową oraz przedsiębiorstw produkujących wybrane elementy systemu, sesje burzy mózgów i własne obserwacje bezwykopowych budów rurociągów. Metodyka identyfikacji czynników ryzyka w bezwykopowej budowie rurociągów z zastosowaniem technologii HDD została szczegółowo omówiona we wcześniejszej pracy autorki (Gierczak, 2013, s. 90-95).

W literaturze można znaleźć szereg istotnych czynników ryzyka i zdarzeń niepożądanych, które mogą wystąpić podczas bezwykopowej budowy rurociągu z zastosowaniem technologii mikrotunelowania (Oreste i in., 2001, s. 33-45; Salem i in., 2017, s. 1014-1021; Shahriar i in., 2007, s. 318-325), HDD (Gierczak, 2014, s. 148-156) oraz przecisków hydraulicznych (Cheng, 2015, s. 48-59). Czynniki te należy koniecznie uwzględnić w ocenie ryzyka.

W proponowanym modelu do analizy ryzyka proponuje się wykorzystać metodę drzewa niezdatności i elementy teorii zbiorów rozmytych. Niepożądane zdarzenia $\mathrm{w}$ bezwykopowej budowie rurociągu należy podzielić na 4 klasy: problemy geotechniczne, problemy ze sprzętem, problemy środowiskowe, problemy z zarządzaniem. Zastosowanie teorii zbiorów rozmytych w eksperckiej ocenie ryzyka $\mathrm{w}$ proponowanym modelu umożliwia zmniejszenie niepewności, braku precyzji i trudności z uzyskaniem liczbowych wartości prawdopodobieństwa zdarzeń podstawowych, które występują w konwencjonalnej analizie drzewa niezdatności. Zbiory rozmyte mają przewagę nad zbiorami nierozmytymi, ponieważ pozwalają na stopniowe przejście pomiędzy różnymi pojęciami, co nabiera szczególnego znaczenia w przypadku konieczności interpretacji wartości lingwistycznych. Takie podejście pozwala na wyeliminowanie trudności w podawaniu konkretnych wartości liczbowych dla prawdopodobieństwa zaistnienia poszczególnych ryzyk, pozwalając zarazem z zastosowaniem defuzyfikacji (przejścia ze zbiorów roztytych do nierozmytych) otrzymać konkretne wartości liczbowe ryzyka dla całego projektu. Ekspercki model jakościowej i ilościowej analizy ryzyka dla jednej z bezwykopowych technologii budowy rurociągów - technologii HDD został szczegółowo omówiony we wcześniejszej pracy autorki niniejszej publikacji (Gierczak, 2014b, s. 67-77).

Celem drugiego etapu zarządzania ryzykiem jest ograniczanie ryzyka do poziomu akceptowalnego poprzez dobór odpowiednich strategii reakcji na ryzyko. Niezwykle istotne jest zestawienie wszystkich zidentyfikowanych możliwości reakcji na ryzyko dla wszystkich zdarzeń niepożądanych w poszczególnych technologiach bezwykopowej budowy, biorąc pod uwagę specyfikę zastosowanej technologii i innowacji. Niektóre innowacyjne przedsiębiorstwa samodzielnie opracowały różne urządzenia i metody stosowane w bezwykopowej budowie rurociągów umożliwiające podjęcie działań na etapie reagowania na ryzyko. Należy je również koniecznie uwzględnić w zestawieniu.

Możliwości reakcji na ryzyko należy pogrupować według podejścia do zarządzania ryzykiem (fatalistyczne lub holistyczne) oraz według rodzaju działania. Dla każdego sugerowanego działania powinno się podać, w której fazie realizacji inwestycji powinno ono być wprowadzone oraz wskazać osoby odpowiedzialne za jego wykonanie. Autorka w swojej pracy doktorskiej (Gierczak, 2013, s. 52-85) opracowała tabelę z proponowanymi 95 strategiami reakcji na ryzyko dla technologii HDD. W miarę upływu czasu i związanego $\mathrm{z}$ tym postępu technicznego tabela ta była przez autorkę uzupełniana i obecnie znajduje się w niej 147 reakcji na ryzyko.

W proponowanym podejściu do zarządzania ryzykiem nie ograniczono się do fatalistycznego podejścia do zarządzania ryzykiem, ale rozważono ryzyko w bardziej proaktywny sposób, poprzez analizę potencjalnego ryzyka i podjęcie środków w celu zredukowania jego przyczyn lub konsekwencji. Podejście proaktywne i holistyczne jest podstawą do eliminacji i redukcji ryzyka. Eliminacja ryzyka zakłada podejmowanie takich działań, żeby ryzyko już nie było obecne (np. wybór innego rozwiązania projektowego). Redukcja ryzyka dotyczy usunięcia jednej lub więcej przyczyn ryzyka, jednej lub więcej konsekwencji ryzyka lub usunięcie przyczyny i konsekwencji ryzyka.

Tolerowanie ryzyka można podzielić na pasywną i aktywną jego akceptację. Pasywna akceptacja ryzyka polega tylko na udokumentowaniu istnienia ryzyka. W tym wypadku firmy wykonawcze biorą na siebie odpowiedzialność za wszelkie konsekwencje związane z zaistnieniem niepożądanych zdarzeń awaryjnych. Aktywna akceptacja ryzyka polega także na udokumentowaniu istnienia ryzyka, ale firma wykonawcza sporządza plany awaryjne, zawierające scenariusze działań, które należy podjąć w przypadku zaistnienia niepożądanego zdarzenia awaryjnego.

Transfer ryzyka wymaga istnienia strony, która będzie chciała ponieść ryzyko. Transfer ryzyka na firmy ubezpieczeniowe jest typowy dla ryzyka o bardzo niskim prawdopodobieństwie wystąpienia i znaczących konsekwencjach. Im wyższe ocenione prawdopodobieństwo zaistnienia niepożądanego zdarzenia, tym większa składka ubezpieczeniowa.

Ignorowanie ryzyka nie jest $\mathrm{w}$ żadnym wypadku zbliżone do tolerowania ryzyka, ponieważ ignorowanie ryzyka zakłada całkowite pominięcie ryzyka możliwego do przewidzenia w sposób nieświadomy lub, co gorsze, w sposób całkowicie świadomy. Ze stosowania szeroko zakrojonej strategii ignorowania ryzyka wynikają znaczne koszty awarii w budownictwie podziemnym.

Podczas tego etapu należy przeprowadzić analizę możliwości wprowadzenia kilku alternatywnych wariantów kombinacji strategii zarządzania ryzykiem, ponownie obliczyć ryzyko dla projektu $\mathrm{z}$ uwzględnieniem redukcji ryzyka wynikającej z możliwych do 
wprowadzenia działań (pętla sprzężenia zwrotnego), porównać uzyskane wyniki dla alternatywnych kombinacji działań i dokonać wyboru najkorzystniejszej kombinacji, która zostanie wprowadzona. Uwzględnienie pętli sprzężenia zwrotnego umożliwia określenie skuteczności różnych rozpatrywanych alternatywnie strategii zarządzania ryzykiem.

Podczas trzeciego etapu zarządzania ryzykiem należy dokonać czynności administracyjnych ryzyka, czyli udokumentować zaistnienie poszczególnych zdarzeń awaryjnych, które wystąpiły podczas bezwykopowej budowy, opracować plany awaryjne na przyszłość na podstawie zdobytych w trakcie realizacji doświadczeń. Należy również opracować plan konserwacji maszyn i narzędzi wiertniczych, a także udokumentować przypadki, w których status czynnika ryzyka został zmieniony na szansę.

Czwarty etap zarządzania ryzykiem stanowi monitorowanie ryzyka. Podczas tego etapu należy wprowadzić poprawki i dokonać aktualizacji stosowanej metody analizy ryzyka. W modelu analizy ryzyka należy uwzględnić postęp technologiczny w danej technologii bezwykopowej budowy, wprowadzone nowe urządzenia i maszyny. Powinno się również uwzględnić dodatkowe, nowo odkryte czynniki ryzyka. Widoczna jest tutaj pętla sprzężenia zwrotnego umożliwiająca wprowadzenie wyżej wymienionych działań.

W piątym etapie zarządzania ryzykiem należy zdefiniować źródła finansowania ryzyka, czyli przewidzieć w budżecie przedsiębiorstwa rezerwę środków finansowych na pokrycie kosztów związanych z zarządzaniem ryzykiem i finansowaniem ubezpieczeń.

We wszystkich etapach procesu zarządzania ryzykiem niezwykle istotna jest wymiana informacji na dwóch płaszczyznach: wewnątrz organizacji (tj. informacji pojawiających się między etapami procesu) oraz z otoczeniem. Pozwala to na dostarczenie nowych, istotnych informacji potrzebnych do podejmowania decyzji na każdym etapie procesu, daje możliwość dostosowania się do zmiennych warunków wewnętrznych i zewnętrznych.

\section{Podsumowanie}

0 becnie coraz więcej przedsiębiorstw zajmujących się budownictwem podziemnym infrastruktury miast podejmuje próby zarządzania ryzykiem $\mathrm{w}$ realizowanych inwestycjach. Niestety, niektóre przedsiębiorstwa nie potrafią efektywnie zarządzać ryzykiem lub wręcz ignorują ryzyko, co jest najbardziej niebezpieczne. Zastosowanie zaproponowanej przez autorkę metodyki procesu zarządzania ryzykiem składającego się z pięciu etapów (ocena ryzyka, reagowanie na ryzyko, administrowanie, monitorowanie i finansowanie ryzyka) pozwala na zmniejszenie liczby sytuacji awaryjnych oraz uchronienie się przed niepożądanymi konsekwencjami ekonomicznymi i prawnymi. Zostało to potwierdzone $\mathrm{w}$ przypadku analizowanej inwestycji w Zastaniu, dla której zastosowano zaprezentowaną w niniejszej pracy autorską metodykę zarządzania ryzykiem, bazującą na podejściu holistycznym i proaktywnym. Inwestycja ta przebiegała bez problemów i została zakończona sukcesem. Wprowadzenie spójnej i skutecznej metodyki zarządzania ryzykiem zaproponowanej przez autorkę znacząco zwiększyło prawdopodobieństwo ukończenia inwestycji z pozytywnym wynikiem.

W przypadku braku spójnej i skutecznej metodyki zarządzania ryzykiem $\mathrm{w}$ analizowanych dwóch inwestycjach w Rudzie Śląskiej i w Katowickiej Strefie Ekonomicznej wystąpiły niepożądane zdarzenia awaryjne, które skutkowały poważnymi konsekwencjami ekonomicznymi i prawnymi (koszty naprawy uszkodzonej jedni, gazociągu, koszty nieudanych inwestycji i kolejnych prób budowy, roszczenia $\mathrm{z}$ tytułu spowodowania zagrożenia życia i zniszczenia mienia). Należy podkreślić, że często bezwykopowe budowy rurociągów są inwestycjami prowadzonymi pod obiektami, takimi jak lotniska, tory kolejowe, mosty, autostrady, budynki i elementy infrastruktury podziemnej miast, co stwarza dodatkowo ryzyko dla inwestycji związane ze zniszczeniem lub uszkodzeniem tych obiektów. Koszty takiej awarii mogą być większe niż całkowity zakontraktowany koszt inwestycji.

Ograniczeniem w zaproponowanym modelu zarządzania ryzykiem jest konieczność zaangażowania ekspertów w etapie oceny ryzyka. Autorka pracuje obecnie nad modelem oceny ryzyka, w którym zostanie wykorzystana sztuczna inteligencja.

\section{dr inż. Maria Krechowicz, Politechnika Świętokrzyska Wydział Zarządzania i Modelowania Komputerowego ORCID: 0000-0002-4213-3149 e-mail: mkrechowicz@tu.kielce.pl}

\section{Przypis}

1) Nazwisko panieńskie autorki: Gierczak.

\section{Bibliografia}

[1] A Guide to the Project Management Body of Knowledge (PMBOK ${ }^{\oplus}$ Guide) (2017), Sixth Edition, PMI, Newton Square, pp. 316-362.

[2] Bizon-Górecka J., Górecki J. (2013), Ryzyko budowlanego projektu inwestycyjnego w perspektywie kosztów budowy, „Przegląd Organizacji”, Nr 6, s. 36-43.

[3] Cheng M. (2015), Developing a Risk Assessment Method for Complex Pipe Jacking Construction Projects, „Automation in Construction", Vol. 58, pp. 48-59.

[4] Damodaran A. (2009), Ryzyko strategiczne. Podstawy zarządzania ryzykiem, Wydawnictwo Akademickie i Profesjonalne, Warszawa.

[5] Gierczak M. (2013), Analiza ryzyka w technologii horyzontalnych przewiertów sterowanych, Praca doktorska, Politechnika Świętokrzyska, Kielce. 
[6] Gierczak M. (2014), The Qualitative Risk Assessment of MINI, MIDI and MAXI Horizontal Directional Drilling Projects, „Tunnelling and Underground Space Technology", No. 44, pp. 148-156.

[7] Gierczak M. (2014a), Wybrane zdarzenia niepożądane $w$ technologii horyzontalnych przewiertów sterowanych (HDD), „Instal”, Nr 3, s. 67-71.

[8] Gierczak M. (2014b), The Quantitative Risk Assessment of MINI, MIDI and MAXI Horizontal Directional Drilling Projects Applying Fuzzy Fault Tree Analysis, „Tunnelling and Underground Space Technology", No. 43, pp. 67-77.

[9] Głodziński E. (2015), Lista kontrolna w zarządzaniu projektami budowlanymi - perspektywa wykonawcy, „Ekonomika i Organizacja Przedsiębiorstwa”, Nr 2, s. 69-80.

[10] Głodziński E. (2014), Zarządzanie projektami w warunkach niepewności - zakres i metodyka, „Przegląd Organizacji”, Nr 7, s. 34-40.

[11] Głodziński E. (2013), Strategiczne zarządzanie przedsięwzięciami $w$ przedsiębiorstwach projektowych - zakres i uwarunkowania, „Przegląd Organizacji”, Nr 3, s. 18-23.

[12] ISO 31000:2018, Risk Management - Guidelines, pp. 1-16.

[13] Krechowicz M. (2017a), Effective Risk Management in Innovative Projects: A Case Study of the Construction of Energy efficient, Sustainable Building of the Laboratory of Intelligent Building in Cracow, „IOP Conference Series: Material Science and Engineering", No. 245062006, pp. 1-10.

[14] Krechowicz M. (2017b), Risk Management in Complex Construction Projects that Apply Renewable Energy Sources: A Case Study of the Realization Phase of the Energis Educational and Research Intelligent Building, „IOP Conference Series: Material Science and Engineering", No. 245062007, pp. 1-10.

[15] Ma B. et al. (2010), Risk Evaluation for Maxi Horizontal Directional Drilling Crossing Projects, „Journal of Pipeline Systems Engineering and Practice", Vol. 1, No. 2, pp. 91-97.

[16] Marciniak S., Głodziński E. (2005), Controlling jako instrument redukujacy poziom niepewności decyzji gospodarczych, [w:] J. Pyka (red.), Nowoczesność przemystu i usług. Współczesne koncepcje i metody zarządzania przedsiębiorstwami, Wyd. TNOiK, Katowice.

[17] Oreste P., Peila D., Marchionni V., Sterling R. (2001), Analysis of the Problems Connected to the Sinking of Micro-TBMs in Difficult Grounds, „Tunnelling and Underground Space Technology", Supplement 1, Vol. 16, pp. 33-45.

[18] Ostrowska E. (2002), Ryzyko projektów inwestycyjnych, Polskie Wydawnictwo Ekonomiczne, Warszawa.

[19] Pritchard C. (2002), Zarzadzanie ryzykiem w projektach. Teoria i praktyka, WIG-Press, Warszawa.

[20] Pszczołowski T. (1978), Mała encyklopedia prakseologii i teorii organizacji, Ossolineum, Warszawa.

[21] Rak J. (2006), Przeglad metod oceny ryzyka zwiazanego z funkcjonowaniem systemów komunalnych, „Instal”, $\mathrm{Nr} 6$, s. $54-56$.

[22] Rak J. (2013), Przeglad unormowań w zakresie zarzadzania ryzykiem, „Instal”, Nr 1, s. 51-53.

[23] Rak J., Tchórzewska-Cieślak B. (2005), Metody analizy $i$ oceny ryzyka $w$ systemie zaopatrzenia $w$ wodę, Oficyna Wydawnicza Politechniki Rzeszowskiej, Rzeszów.
[24] Rak J., Tchórzewska-Cieślak B., Studziński A., Pietrucha-Urbanik K., Boryczko K. (2013), Niezawodność i bezpieczeństwo systemów zbiorowego zaopatrzenia $w$ wodę, Oficyna Wydawnicza Politechniki Rzeszowskiej, Rzeszów.

[25] Salem D., Elwakil E., Hegab M. (2017), Risk Level Problems Affecting Microtunneling Projects Installation, „Canadian Journal of Civil Engineering”, Vol. 44, No. 12, pp. 1014-1021.

[26] Shahriar K., Sharifzadeh M., Hamidi J. K. (2007), Geotechnical Risk Assessment Based Approach for Rock TBM Selection in Difficult Ground Conditions, „Tunnelling and Underground Space Technology", Vol. 23, No. 3, pp. 318-325.

[27] Skorupka D. (2005), Zarządzanie ryzykiem projektu $w$ inwestycjach budowlanych, Wydawnictwo Akademii Świętokrzyskiej, Kielce.

[28] Tworek P. (2012), Integrated Risk Management in Construction Enterprises - Theoretical Approach, „Journal of Econimics and Management", Vol. 8, pp. 126-135.

[29] Tworek P. (2013), Reakcja na ryzyko w działalności przedsiębiorstwa budowlano-montażowego, Difin, Warszawa.

[30] Smith N.J., Merna T., Jobling P. (2006), Managing Risk in Construction Projects, Wiley-Blackwell, Oxford.

[31] Van Staveren M. (2007), Uncertainty and Ground Conditions. A Risk Management Approach, ButterworthHeinemann, Burlington.

\section{Risk Management Methodology for Underground Construction of Urban Underground Utilities}

\section{Summary}

Currently, we can observe an intensive development of underground infrastructure in cities around the world. This paper discusses the principles of risk management in underground construction of urban infrastructure. The author also presents own risk management methodology for trenchless constructions of pipelines applying various technologies. The risk management process in underground construction of urban utilities has been divided into five stages: risk assessment, selection of the risk treatment, risk register, risk monitoring and financing. Three selected, representative cases of the application of various risk management strategies in underground constructions have also been analysed. The analysis has shown that the introduction of the risk management strategy proposed by the author significantly increased the probability of completing the investment with a positive result, allowing to avoid emergency situations and to prevent adverse economic and legal consequences. In case of the two analysed investments, in which no consistent and effective risk management methodology was applied, undesirable unwanted events occurred, which resulted in serious economic and legal consequences.

\section{Keywords}

risk management, risk assessment, underground construction, trenchless technology 